\title{
An Estimate of Energy Available via Microbial Sulfate Reduction at a Quaternary Aquifer in Northern Japan considered for Low Temperature Thermal Energy Storage
}

\section{Seiichiro Ioka * and Hirofumi Muraoka}

North Japan Research Institute for Sustainable Energy, Hirosaki University, 2-1-3 Matsubara, Aomori 030-0813, Japan; E-Mail: hiro@cc.hirosaki-u.ac.jp

* Author to whom correspondence should be addressed; E-Mail: ioka@cc.hirosaki-u.ac.jp; Tel.: +81-17-762-7739; Fax: +81-17-735-5411.

Received: 18 January 2014; in revised form: 16 March 2014 / Accepted: 19 March 2014 /

Published: 9 April 2014

\begin{abstract}
The energy available via microbial sulfate reduction was estimated for a Quaternary aquifer in northern Japan that is a candidate site for low temperature aquifer thermal energy storage. In evaluating whether microbial sulfate reduction proceeded or ceased, it was assumed that electron donor/acceptor concentrations were unchanged by temperature increase. The estimated energy availability via microbial sulfate reduction at $9^{\circ} \mathrm{C}$ with no thermal disturbance was 37,51 , and $53 \mathrm{~kJ} \cdot\left(\mathrm{mol} \mathrm{SO}_{4}{ }^{2-}\right)^{-1}$. The low estimate of $37 \mathrm{~kJ} \cdot\left(\mathrm{mol} \mathrm{SO}{ }_{4}{ }^{2-}\right)^{-1}$ was attributed to low concentration of $\mathrm{SO}_{4}{ }^{2-}$. Excluding the sampling site with low concentration of electron acceptors, energy availability was estimated 52 and $54 \mathrm{~kJ} \cdot\left(\mathrm{mol} \mathrm{SO}{ }_{4}{ }^{2-}\right)^{-1}$ at $20{ }^{\circ} \mathrm{C}$; 54 and $57 \mathrm{~kJ} \cdot\left(\mathrm{mol} \mathrm{SO}{ }_{4}{ }^{2-}\right)^{-1}$ at $40{ }^{\circ} \mathrm{C}$; and 57 and $59 \mathrm{~kJ} \cdot\left(\mathrm{mol} \mathrm{SO}{ }_{4}{ }^{2-}\right)^{-1}$ at $60{ }^{\circ} \mathrm{C}$. These results indicate that possible energy availability via microbial sulfate reduction at approximately $40-60{ }^{\circ} \mathrm{C}$ exceeded the range of available energy (compiled from previous studies) at which sulfate reduction would cease. Thus, microbial sulfate reduction at this site may proceed at approximately $40-60{ }^{\circ} \mathrm{C}$.
\end{abstract}

Keywords: energy availability; microbial sulfate reduction; low temperature thermal storage; Quaternary aquifer; northern Japan 


\section{Introduction}

Aquifer thermal energy storage, which is the subsurface storage of excess solar thermal energy and exhaust heat from air conditioners, is an effective way to bridge hot summer months [1]. However, groundwater contained within an aquifer is an important resource for the world's agricultural, industrial, and drinking-water requirements [2]. Thermal energy storage may often be implemented in the same aquifers that supply drinking water. The preservation of groundwater requires an understanding of the quality of groundwater [3]. Thus, the effects of aquifer thermal energy storage on groundwater quality must be identified [4,5]. The redox reactions are significant geochemical processes that determine the quality of natural groundwater [6,7]. Previous studies on that issue have examined redox chemistry [8-10]. Microbial sulfate reduction is a particularly important redox reaction (see Equation (1), below), as it produces hydrogen sulfide — a highly toxic compound that can form in any aqueous system which contains both organic matter and sulfate [11].

$$
\mathrm{CH}_{3} \mathrm{COO}^{-}+\mathrm{SO}_{4}^{2-}+\mathrm{H}^{+} \rightarrow 2 \mathrm{HCO}_{3}^{-}+\mathrm{H}_{2} \mathrm{~S}(\mathrm{aq})
$$

In addition, sulfate reduction can cause anaerobic corrosion of ferrous metals, and to a lesser degree stainless steel, thereby reducing the lifespan of the thermal storage system [10]. In recent studies of the effects of aquifer thermal storage, Jesußek et al. [1] and Bonte et al. [10] reported a shift from iron reduction to sulfate reduction at $70{ }^{\circ} \mathrm{C}$ and $25{ }^{\circ} \mathrm{C}$ respectively. Both studies employed laboratory experiments. Jesußek et al. [1] identified that redox zoning shifted from oxic conditions toward nitrate and iron (III) reducing conditions at 25 and $40{ }^{\circ} \mathrm{C}$, and toward sulfate reducing conditions at $70{ }^{\circ} \mathrm{C}$ in column experiments with Tertiary lignite sand at $10,25,40$, and $70{ }^{\circ} \mathrm{C}$. On the other hand, Bonte et al. [10] reported that a temperature increase from $11{ }^{\circ} \mathrm{C}$ to $25{ }^{\circ} \mathrm{C}$ caused a shift from iron-reducing to sulfate-reducing and methanogenic conditions in column experiments at 5, 11, 25, and $60{ }^{\circ} \mathrm{C}$ with sediments collected from an unconsolidated sandy aquifer that was deposited during the Early to Middle Pleistocene. The large difference in temperature at which the shift in redox conditions occurred might be associated with the rate of supply of an electron donor for sulfate reduction caused by the difference in sedimentary age or the reactivity of organic matter, i.e., the release of organic carbon from the experimental sediment to solution was small except in the laboratory experiment at $70{ }^{\circ} \mathrm{C}$ in Jesußek et al. [1]. However, previous studies have not estimated the availability of energy from microbial sulfate reduction with low temperature thermal storage in conditions where electron donor concentrations were unchanged by temperature increase. Thus, it remains to be determined whether the calculated energy availability is within the energy range (compiled from previous studies [12]) at which sulfate reduction would cease.

Since the 2011 Tohoku earthquake, almost all of Japan's nuclear power stations have been shut down; subsequently, greater reliance on fossil fuels will result in higher carbon dioxide emissions. Particularly, the cold, snowy areas of northern Japan need thermal energy for snow melting and heating, etc. Thus, there is significant opportunity to increase the utilization of underground thermal energy used and storage [13]. However, there are few studies on the chemical effects of low temperature aquifer thermal storage on groundwater quality in Japan.

Thus, as a preliminary evaluation of whether microbial sulfate reduction is likely to proceed or cease, this study investigates the energy availability via microbial sulfate reduction with low 
temperature thermal storage, assuming no change of electron donor/acceptor concentrations with temperature increase. Groundwater quality data are obtained from a Quaternary aquifer in northern Japan that is considered to be a promising test site for aquifer thermal storage. This study examines whether the calculated energy availability falls within the range (compiled from previous studies [12]) at which sulfate reduction would cease, and reports the possibility of microbial sulfate reduction for future experiments with low temperature thermal storage at the site.

\section{Materials and Methods}

\subsection{Study Site}

The Japanese archipelago has a unique combination of geologic, geomorphic, and climatic features including relatively recent geology, complex geomorphology, and frequently heavy rains [14], such that groundwater resources are mainly contained in Quaternary aquifer systems deposited in Tertiary vessels [15]. Therefore, it is very important to understand the geochemical processes that control groundwater quality within Quaternary aquifer systems in Japan. The study site is located at a northwestern peninsula of Hokkaido, in northern Japan (Figure 1). It is situated on a low-lying coastal plain, named Sarobetu-genya, comprising Quaternary alluvial and terrace deposits overlying Neogene rocks [16]. The site has annual precipitation of $877 \mathrm{~mm}$, average annual temperature of $6.2^{\circ} \mathrm{C}$, and maximum snow depth of $780 \mathrm{~mm}$ [17].

Figure 1. Study area, location of piezometers, and geological map (data from [18]). The A-B line is a topographical transect shown in Figure 2.

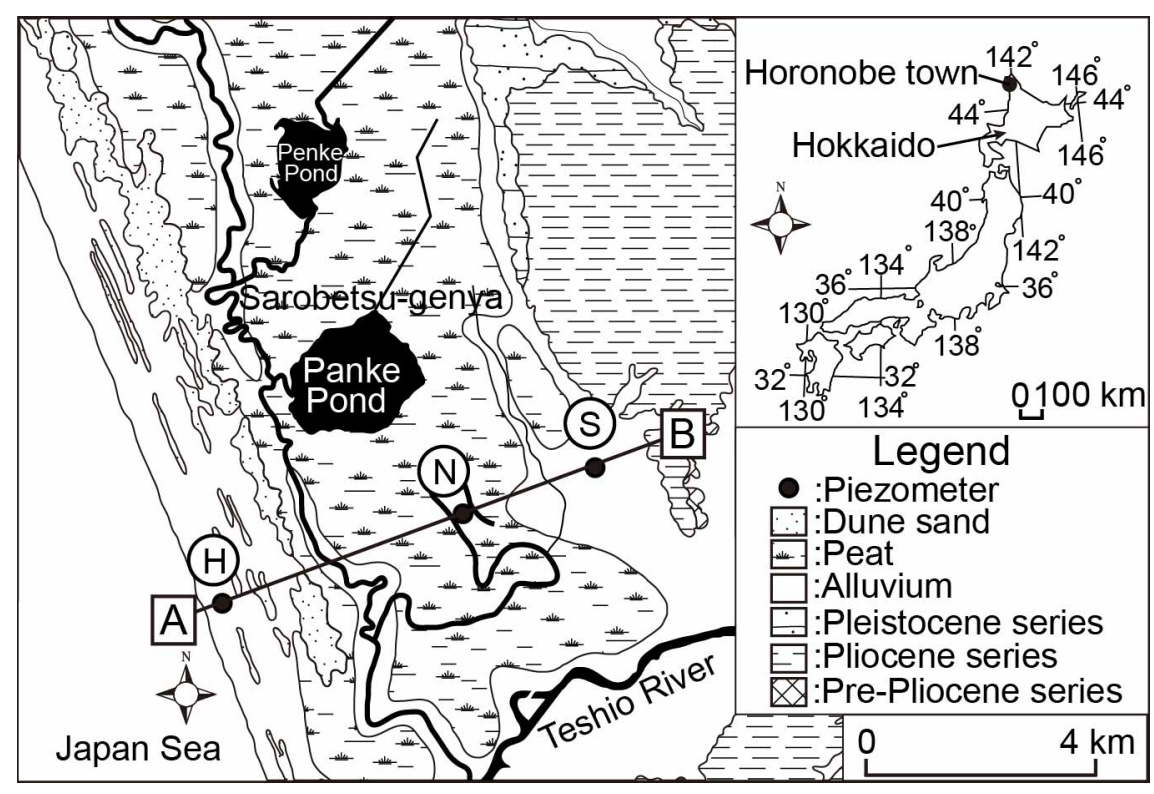

The Quaternary deposits at the study site are alluvial (Holocene) deposits comprising surface soil, silty fine sand, sand and gravel, medium sand, coarse sand with gravel, and sand (Figure 2 and Table 1). Hydraulic conductivities were previously reported for silty fine sand $\left(7.5 \times 10^{-6} \mathrm{~ms}^{-1}\right)$, sand and gravel (from $3.1 \times 10^{-4}$ to $9.2 \times 10^{-7} \mathrm{~ms}^{-1}$ ), medium sand $\left(2.3 \times 10^{-4} \mathrm{~ms}^{-1}\right.$ ), and coarse sand with gravel $\left(1.6 \times 10^{-4} \mathrm{~ms}^{-1}\right)$ [19]. The groundwater temperature is approximately $9{ }^{\circ} \mathrm{C}$. The directions of 
groundwater flow are from Shimonuma Hill to Sarobetsu-genya; from the beach-ridge dune system to Sarobetsu-genya; and from the beach-ridge, dune to the Japan Sea, because the beach-ridge, dune system forms a water table divide [19].

Table 1. Lithostratigraphic formations discussed in this study (after [20]).

\begin{tabular}{cccc}
\hline Site & $\begin{array}{c}\text { Geological } \\
\text { period }\end{array}$ & $\begin{array}{c}\text { Depositional } \\
\text { environment }\end{array}$ & $\begin{array}{c}\text { Total organic carbon and total sulfur contents } \\
(\mathbf{w t} \%) \text { near the screens }\end{array}$ \\
\hline $\mathrm{H}$ & Holocene & Marine & 1.97 and 1.18 at depth of $15.15 \mathrm{~m}$ \\
$\mathrm{~N}$ & Holocene & Freshwater & 1.24 and 0.14 at depth of $10.50 \mathrm{~m}$ \\
$\mathrm{~S}$ & Holocene & Marine & 0.48 and 0.21 at depth of $13.25 \mathrm{~m}$ \\
\hline
\end{tabular}

Figure 2. Topographical transects, stratigraphic profiles at piezometer locations, depths of piezometer screens, and groundwater levels. No data at site H. (data from [19]).
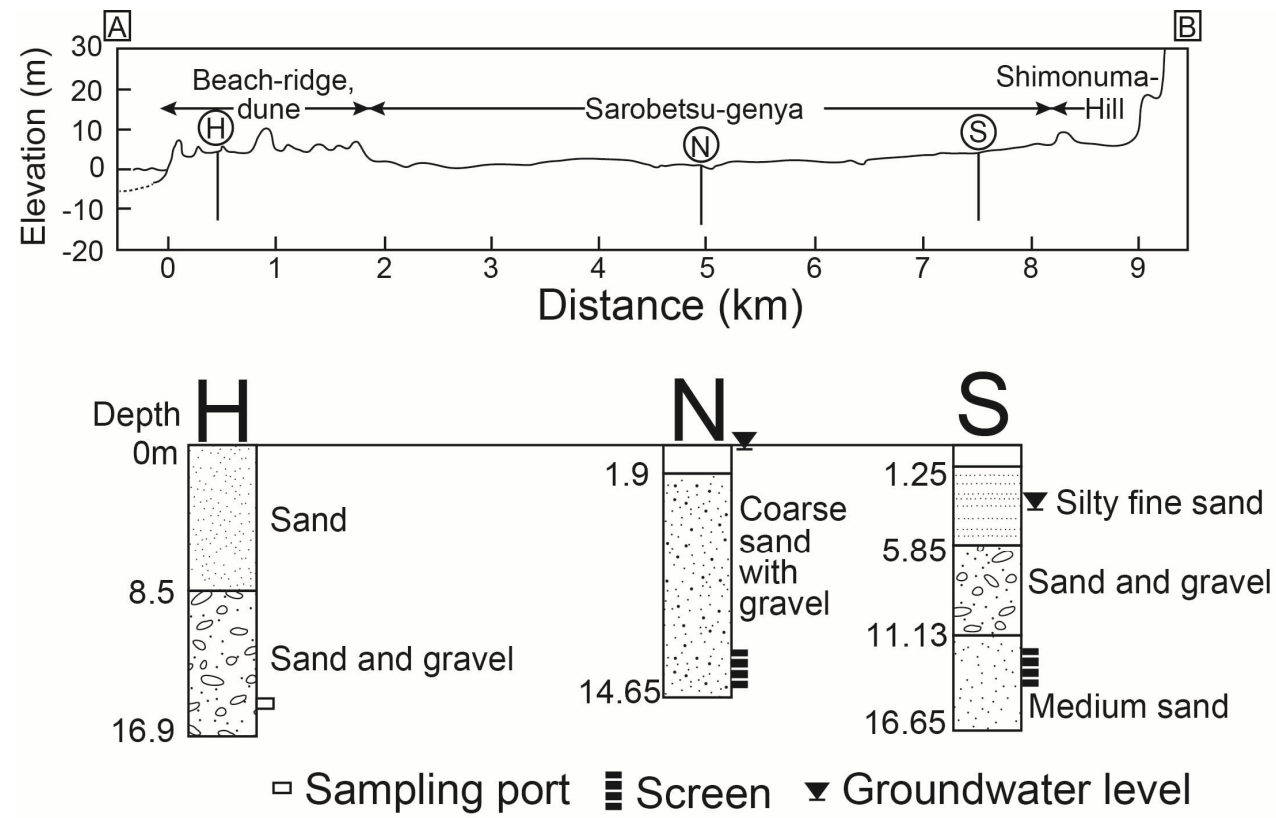

\subsection{Sampling Method}

Piezometers were installed at three locations near the coast, Sarobetsu-genya, and near Shimonuma Hill, considered the topography of the site and drilling costs. Piezometers fitted with screens were placed from $12 \mathrm{~m}$ to $14 \mathrm{~m}$ below the groundwater surface at sites $\mathrm{S}$ and $\mathrm{N}$ (shown in Figure 1). The piezometers used at sites $\mathrm{S}$ and $\mathrm{N}$ were constructed from polyvinylchloride pipes of $0.05 \mathrm{~m}$ inner diameter. The piezometer used at site $\mathrm{H}$ was constructed from nylon tube of $4 \mathrm{~mm}$ inner diameter, and the sampling port was located at a depth of $15 \mathrm{~m}$ below the groundwater surface.

Prior to groundwater sampling, at least one volume of standing water was removed from within the piezometers. Subsequently, groundwater samples were collected from the three piezometers on 24 July, 10 August, and 26 August, 2009. The $\mathrm{pH}$, specific electrical conductivity (SEC), and $\mathrm{S}^{2-}$ were determined at the sampling site with a temperature-compensated electronic portable $\mathrm{pH}$ meter (model HM-20P, DKK-TOA Co., Tokyo, Japan), EC meter (model HM-21P, DKK-TOA Co.), and a spectrophotometer (model DR2800, Hach Company, Loveland, CO, USA), respectively. The $\mathrm{S}^{2-}$ 
concentrations, measured using the methylene blue method (Method 8131, Hach Company), indicate total sulfide (sum of $\mathrm{H}_{2} \mathrm{~S}, \mathrm{HS}^{-}$, and $\mathrm{S}^{2-}$ species). A $100-\mathrm{mL}$ polyethylene bottle was used to collect groundwater for analysis of $\mathrm{Fe}, \mathrm{Mn}, \mathrm{Si}, \mathrm{P}$, and $\mathrm{Ba}$ : the water was filtered $(0.2-\mu \mathrm{m}$ pore size polytetrafluoroethylene (PTFE) filters, DISMIC-25 $\mathrm{HP}$ ) and acidified to $\mathrm{pH}<2$ with ultra-pure nitric acid. Filtered and non-acidified water was also collected for chemical analysis of cations $\left(\mathrm{Na}^{+}, \mathrm{NH}_{4}^{+}\right.$, $\mathrm{K}^{+}, \mathrm{Mg}^{2+}$, and $\left.\mathrm{Ca}^{2+}\right)$ and anions $\left(\mathrm{F}^{-}, \mathrm{CH} 3 \mathrm{COO}^{-}, \mathrm{Cl}^{-}, \mathrm{NO}_{3}{ }^{-}\right.$, and $\left.\mathrm{SO}_{4}{ }^{2-}\right)$ in $100-\mathrm{mL}$ polyethylene bottles; and dissolved organic carbon (DOC) in 50-mL glass vials. The water samples analyzed for alkalinity and $\mathrm{CH}_{4}$ were unfiltered, and were collected in $100-\mathrm{mL}$ polyethylene bottles and $125-\mathrm{mL}$ glass vials respectively.

\subsection{Analyses}

The concentrations of $\mathrm{Fe}, \mathrm{Mn}, \mathrm{Sr}, \mathrm{P}$, and $\mathrm{Ba}$ were analyzed by an inductively coupled plasma atomic emission spectrometer (ICPS-7510, Shimadzu Co., Kyoto, Japan); those of $\mathrm{Na}^{+}, \mathrm{NH}_{4}^{+}, \mathrm{K}^{+}$, $\mathrm{Mg}^{2+}$, and $\mathrm{Ca}^{2+}$ were analyzed by ion chromatography with conductivity detection via an ICS-1000 (Thermo Fisher Scientific Inc., Waltham, MA, USA); and those of $\mathrm{F}^{-}, \mathrm{CH}_{3} \mathrm{COO}^{-}, \mathrm{Cl}^{-}, \mathrm{NO}_{3}^{-}, \mathrm{SO}_{4}{ }^{2-}$ were analyzed by ion chromatography with conductivity detection using a 761 Compact IC (Metrohm Schweiz AG, Herisau, Switzerland). The DOC was measured with a total organic carbon (TOC) analyzer (TOC- $\mathrm{V}_{\mathrm{CSH}}$, Shimadzu Co.); $\mathrm{CH}_{4}$ was measured in the headspace gas expanded from glass vials into a gas chromatograph (GC-14B, Shimadzu Co.); and aqueous concentrations were determined using the Bunsen solubility coefficient and reported in milligrams per liter of water. Alkalinity was determined in the laboratory using TITRONIC basic (SCHOTT, Mainz, Germany) with N/50 $\mathrm{H}_{2} \mathrm{SO}_{4}$ and presented as the concentration of $\mathrm{HCO}_{3}{ }^{-}$in milligrams per liter of water. Analytical precision (i.e., coefficient of variation for triplicate measurements) was within $2 \%$ for $\mathrm{Fe}, \mathrm{Mn}, \mathrm{Sr}, \mathrm{P}$, and $\mathrm{Ba} ; 2 \%$ for DOC; $4 \%$ for $\mathrm{CH}_{4} ; 2 \%$ for $\mathrm{Na}^{+}, \mathrm{NH}_{4}{ }^{+}, \mathrm{K}^{+}, \mathrm{Mg}^{2+}$, and $\mathrm{Ca}^{2+}$ (except $4 \%$ for $\mathrm{NH}_{4}{ }^{+}$at site $\mathrm{S}$ ); and $2 \%$ for $\mathrm{F}^{-}, \mathrm{CH}_{3} \mathrm{COO}^{-}, \mathrm{Cl}^{-}, \mathrm{NO}_{3}{ }^{-}$, and $\mathrm{SO}_{4}{ }^{2-}$ (except $8 \%$ for $\mathrm{SO}_{4}{ }^{2-}$ at site $\mathrm{H}$; and $5 \%, 12 \%$, and $25 \%$ for $\mathrm{CH}_{3} \mathrm{COO}^{-}$at sites $\mathrm{H}, \mathrm{N}$, and $\mathrm{S}$, respectively). Furthermore, the errors in the charge balances between the cations and anions were less than $\pm 1 \%$ at site $\mathrm{H}, \pm 4 \%$ at site $\mathrm{N}$, and $\pm 2 \%$ at site $\mathrm{S}$. The charge balances of groundwater samples were calculated using the aqueous speciation code from the PHREEQC [21] thermodynamic database (phreeqc. dat). Additionally, the solubility constant used was $\log K=-3.0$ for amorphous FeS [22]. The pe values used for the calculations with the PHREEQC were those of the $\mathrm{CH}_{4} / \mathrm{CO}_{2}$ redox couple.

\subsection{Geochemical Modeling of Energy Availability}

The energy available via microbial sulfate reduction was calculated from the activities of $\mathrm{CH}_{3} \mathrm{COO}^{-}, \mathrm{SO}_{4}{ }^{2-}, \mathrm{H}^{+}, \mathrm{HCO}_{3}{ }^{-}$, and $\mathrm{H}_{2} \mathrm{~S}$ as the Gibbs free energies of chemical reaction $(\Delta G)$ with the Gibbs free energies of formation $\left(\Delta G^{0}\right)$ at a groundwater temperature of $9{ }^{\circ} \mathrm{C}$ with no thermal disturbance; and at $20{ }^{\circ} \mathrm{C}, 40{ }^{\circ} \mathrm{C}$, and $60{ }^{\circ} \mathrm{C}$ with low temperature thermal storage, assuming that the electron donor and acceptor concentrations were unchanged with temperature increase. The assumption is made because it is unclear whether or not those concentrations would increase, as there are no prior experimental data for aquifer thermal energy storage. The only measured $\mathrm{CH}_{3} \mathrm{COO}^{-}$ concentrations were utilized as activities of $\mathrm{CH}_{3} \mathrm{COO}^{-}$. The chemical reaction equations for microbial 
sulfate reduction and the Gibbs free energies of formation $\left(\Delta G^{0}\right)$ were derived using the Rxn module in Geochemist's Workbench software (Ver. 9.08) [23] with the thermo.comv8.r6+.dat thermodynamic data. The Gibbs free energies of formation $\left(\Delta G^{0}\right)$ are shown in Table 2. The ion activities and saturation index (SI) of groundwater samples were also calculated using aqueous speciation code of the PHREEQC with $9{ }^{\circ} \mathrm{C}$.

Table 2. Chemical reactions and associated standard free energy change $\Delta G^{0}$ for sulfate reduction, calculated using $\mathrm{CH}_{3} \mathrm{COO}^{-}$as electron donor in terms of the transfer of eight electrons.

\begin{tabular}{ccc}
\hline Sulfate reduction & $\Delta \boldsymbol{G}^{\mathbf{0}} \mathbf{( \mathbf { k J m o l } ^ { - \mathbf { 1 } } )}$ & Temperature $\left({ }^{\circ} \mathrm{C}\right)$ \\
\hline & -84.77 & 9 \\
$\mathrm{CH}_{3} \mathrm{COO}^{-}+\mathrm{SO}_{4}{ }^{2-}+\mathrm{H}^{+} \rightarrow 2 \mathrm{HCO}_{3}{ }^{-}+\mathrm{H}_{2} \mathrm{~S}(\mathrm{aq})$ & -87.03 & 20 \\
& -91.45 & 40 \\
& -96.27 & 60 \\
\hline
\end{tabular}

This study used a value of $56 \mathrm{~kJ} \cdot\left(\mathrm{mol} \mathrm{SO}_{4}{ }^{2-}\right)^{-1}$ reported by Jin and Bethke [12] as the energy availability threshold at which microbial sulfate reduction proceeds. Jin and Bethke [12] reported that in pure culture experiments, acetotrophic sulfate reduction ceases when the energy liberated by the reaction decreases to $33-43 \mathrm{~kJ} \cdot\left(\mathrm{mol} \mathrm{SO}_{4}{ }^{2-}\right)^{-1}$, and in experiments with microbial consortia as well as in nature, an overlapping range of $40-56 \mathrm{~kJ} \cdot\left(\mathrm{mol} \mathrm{SO}_{4}{ }^{2-}\right)^{-1}$ is observed where sulfate reduction ceases. In addition, the energy availability thresholds are assumed to be constant in relation to temperature change: $53.4 \mathrm{~kJ} \cdot\left(\mathrm{mol} \mathrm{SO}_{4}{ }^{2-}\right)^{-1}$ at $8{ }^{\circ} \mathrm{C}$ and $53.5 \mathrm{~kJ} \cdot\left(\mathrm{mol} \mathrm{SO}_{4}{ }^{2-}\right)^{-1}$ at $20{ }^{\circ} \mathrm{C}$ in the compiled data reported by Jin and Bethke [12].

\section{Results and Discussion}

The results of chemical analyses are shown in Table 3. The groundwaters at sites $\mathrm{H}, \mathrm{N}$, and $\mathrm{S}$ all showed sodium-bicarbonate type water as major chemical components. The concentrations of sulfate-reduction-sensitive species in groundwater were $0.026-0.039 \mathrm{mg} / \mathrm{L}\left(\mathrm{CH}_{3} \mathrm{COO}^{\top}\right), 0.024-6.50 \mathrm{mg} / \mathrm{L}$ $\left(\mathrm{SO}_{4}{ }^{2}\right), 0.047-0.095 \mathrm{mg} / \mathrm{L}\left(\mathrm{S}^{2-}\right), 81.8-157\left(\mathrm{HCO}_{3}{ }^{-}\right)$, and $6.62-8.04(\mathrm{pH})$. The groundwater concentrations of other redox species were 0.225-9.80 mg/L $\left(\mathrm{CH}_{4}\right), 0.129-28.4 \mathrm{mg} / \mathrm{L}(\mathrm{Fe})$, 0.101-0.595 mg/L (Mn), 0.304-0.928 mg/L $\left(\mathrm{NH}_{4}{ }^{+}\right)$, and not detected $\left(\mathrm{NO}_{3}{ }^{-}\right)$. The samples would all display reduced redox conditions because the groundwaters contain abundant redox species $\mathrm{CH}_{4}, \mathrm{~S}^{2-}$, $\mathrm{Fe}$, and $\mathrm{Mn}$. The groundwater at site $\mathrm{N}$ has high $\mathrm{CH}_{4}$ and $\mathrm{SO}_{4}{ }^{2-}$ concentrations. Closely spaced zones with different redox processes might be common in this aquifer. Thus, these high concentrations at site $\mathrm{N}$ might be due to mixed redox processes in the piezometer [24]. In addition, at site $\mathrm{H}$, the low $\mathrm{SO}_{4}{ }^{2-}$ concentration relative to the other sites might be a result of a difference in groundwater flow paths if the groundwater at site $\mathrm{H}$ does not pass sulfate supply zones; or might be a result of a microbial sulfate reduction during infiltration processes in the shallower depth, although this was not identified in this study. 
Table 3. Chemical composition of groundwater samples from piezometers.

\begin{tabular}{cccc}
\hline Sampling date & 26 August 2009 & 10 August 2009 & 24 July 2009 \\
\hline Location $^{\mathrm{a}}$ & $\mathrm{H}$ & $\mathrm{N}^{\mathrm{b}}$ & $\mathrm{S}$ \\
$\mathrm{pH}^{\mathrm{a}}$ & 8.04 & 6.70 & 6.62 \\
$\mathrm{DOC}^{-}$ & 2.05 & 2.39 & 0.72 \\
$\mathrm{CH}_{3} \mathrm{COO}^{-}$ & 0.026 & 0.039 & 0.027 \\
$\mathrm{~F}^{-}$ & 0.123 & 0.046 & 0.063 \\
$\mathrm{Cl}^{-}$ & 39.2 & 54.1 & 20.0 \\
$\mathrm{NO}_{3}^{-}$ & $\mathrm{n} / \mathrm{d}$ & $\mathrm{n} / \mathrm{d}$ & $\mathrm{n}$ \\
$\mathrm{SO}_{4}^{2-}$ & 0.024 & 6.50 & 5.45 \\
$\mathrm{~S}^{2-}$ & 0.047 & 0.095 & 0.088 \\
$\mathrm{HCO}^{-}$ & 127 & 152 & 81.8 \\
$\mathrm{Na}^{+}$ & 22.1 & 29.2 & 12.7 \\
$\mathrm{NH}_{4}^{+}$ & 0.691 & 0.928 & 0.304 \\
$\mathrm{~K}^{+}$ & 10 & 6.2 & 1.6 \\
$\mathrm{Mg}^{2+}$ & 13.8 & 17.6 & 10.9 \\
$\mathrm{Ca}^{2+}$ & 16.6 & 9.84 & 3.85 \\
$\mathrm{P}$ & 0.803 & 0.644 & 0.636 \\
$\mathrm{Fe}$ & 0.129 & 28.4 & 11.3 \\
$\mathrm{Mn}_{\mathrm{Sr}}$ & 0.101 & 0.595 & 0.242 \\
$\mathrm{Ba}$ & 0.125 & 0.147 & 0.040 \\
$\mathrm{Si}$ & 0.009 & 0.218 & 0.052 \\
$\mathrm{CH}_{4}$ & 13.2 & 18.8 & 20 \\
\hline $\mathrm{Nat}$ & 1.11 & 9.8 & 0.225 \\
\hline
\end{tabular}

Notes: $\mathrm{n} / \mathrm{d}$ : Not detected; ${ }^{\mathrm{a}} \mathrm{pH}$ : All other concentrations are in $\mathrm{mg} / \mathrm{L} ;{ }^{\mathrm{b}}$ Except $\mathrm{CH}_{3} \mathrm{COO}^{-}$, after Ioka et al. [25].

The energy available from microbial sulfate reduction with no thermal disturbance, and the potential energy available from microbial sulfate reduction with low temperature thermal storage were estimated as a preliminary evaluation of whether microbial sulfate reduction might proceed or cease, with a view to future experiments on low temperature thermal storage at the site. The low temperature thermal storage scenario assumed that the concentrations of electron donor and electron acceptor were unchanged with temperature increase. The results (see Figure 3) at a temperature of $9{ }^{\circ} \mathrm{C}$ were 36,51 , and $53 \mathrm{~kJ} \cdot\left(\mathrm{mol} \mathrm{SO}_{4}{ }^{2-}\right)^{-1}$ at the $\mathrm{H}, \mathrm{N}$, and $\mathrm{S}$ sites, respectively. The low estimate of $36 \mathrm{~kJ} \cdot\left(\mathrm{mol} \mathrm{SO}_{4}{ }^{2-}\right)^{-1}$ at the $\mathrm{H}$ site might be due to low $\mathrm{SO}_{4}{ }^{2-}$ concentration $(0.024 \mathrm{mg} / \mathrm{L})$. Although the present study did not measure whether microbial sulfate reduction proceeded or ceased, given the threshold of $56 \mathrm{~kJ} \cdot\left(\mathrm{mol} \mathrm{SO}_{4}{ }^{2-}\right)^{-1}$, microbial sulfate reduction might be assumed to have ceased in the absence of thermal disturbance. For microbial sulfate reduction with low temperature thermal storage assuming constant electron donor/acceptor concentrations, the estimated potential energy available at $\sim 40{ }^{\circ} \mathrm{C}$ at site $\mathrm{S}$ and $\sim 60{ }^{\circ} \mathrm{C}$ at site $\mathrm{N}$ exceeded the threshold value compiled from previous studies [12]. Although it was unclear why the results differed for sites $\mathrm{S}$ and $\mathrm{N}$, microbial sulfate reduction at those sites may proceed at approximately $40-60{ }^{\circ} \mathrm{C}$, i.e., sulfate reduction may not proceed at $25{ }^{\circ} \mathrm{C}$ and $40{ }^{\circ} \mathrm{C}$. These results support the results of column experiments reported by Jesußek et al. [1] using an initial solution of $\mathrm{pH}$ : 7.55 , TIC: $5.63 \mathrm{mmol} / \mathrm{L}$, DOC: $0.24 \mathrm{mmol} / \mathrm{L}, \mathrm{SO}_{4}{ }^{2-}: 0.16 \mathrm{mmol} / \mathrm{L}$ as average composition and Tertiary lignite sand. In that study, microbial sulfate reduction could not proceed 
because there was limited release of electron donors from the experimental sediment to solution in the laboratory experiment at 25 and $40{ }^{\circ} \mathrm{C}$ except that at $70{ }^{\circ} \mathrm{C}$. In addition, there are many reports that microbial sulfate reduction proceeded in Holocene and Pleistocene aquifer sediments even low temperature $[7,26]$. However, these results identified that the zone where microbial sulfate reduction proceed was heterogeneously distributed even in comparatively homogeneous sand sediments. The heterogeneous in Holocene and Pleistocene aquifer sediments might be caused by the heterogeneous distribution of reactivity of organic matter. Thus, establishing the chemical effects of low temperature aquifer thermal storage on groundwater quality considering the distribution of reactivity of organic matter will require further examination at the site, via field tests or laboratory experiments.

Figure 3. Calculated thermodynamic energy available via microbial sulfate reduction using acetate as an electron donor.

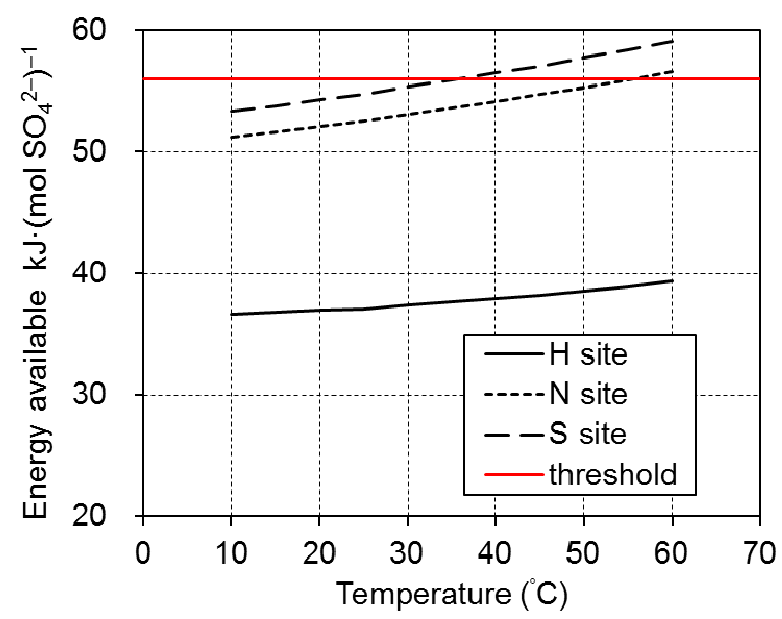

\section{Conclusions}

The study examines whether microbial sulfate reduction is likely to proceed or cease at a candidate site for low temperature aquifer thermal storage. The site is located in a cold, snowy area of northern Japan where thermal energy is required for snow melting and heating, etc. The possible energy available from microbial sulfate reduction with thermal storage was estimated, assuming constant electron donor/acceptor concentrations with temperature increase. The results indicate that the energy available at temperature higher than $\sim 40-60{ }^{\circ} \mathrm{C}$ exceeded the range of available energy (33-56 $\mathrm{kJ} \cdot\left(\mathrm{mol} \mathrm{SO}{ }_{4}{ }^{2-}\right)^{-1}$ compiled from previous studies) at which sulfate reduction would cease. Therefore, microbial sulfate reduction at this site might proceed at approximately $40-60{ }^{\circ} \mathrm{C}$ with low temperature aquifer thermal storage. Further investigation of this issue is important for preserving groundwater quality in relation to aquifer thermal storage.

\section{Acknowledgments}

This study was partly funded by the Ministry of Economy, Trade and Industry of Japan and a Grant-in-Aid of Scientific Research (A) (No. 23246155), a Grant-in-Aid of Scientific Research (B) (No. 25289332), and Grant-in-Aid of Scientific Research (C) (No. 25350418). We thank Toshiaki Sakai; Hiroyuki Tada; and Masako Takahashi for providing field and laboratory assistance. 
We are also grateful to Nippon Koei Co., Ltd. (Tokyo, Japan), and ACE-Shisui Co., Ltd. (Sapporo, Japan), for drilling and installing the piezometers. Appreciation is also extended to the individual on whose property the piezometer was installed.

\section{Author Contributions}

Seiichiro Ioka designed and performed the research and wrote the manuscript. Hirofumi Muraoka contributed the manuscript.

\section{Conflicts of Interest}

The authors declare no conflict of interest.

\section{References}

1. Jesußek, A.; Grandel, S.; Dahmke, A. Impact of subsurface heat storage on aquifer hydrogeochemistry. Environ. Earth Sci. 2013, 69, 1999-2012.

2. Gleeson, T.; VanderSteen, J.; Sophocleous, M.A.; Taniguchi, M.; Alley, W.M.; Allen, D.M.; Zhou, Y. Groundwater sustainability strategies. Nature Geosci. 2010, 3, 378-379.

3. Edmunds, W.M. Geochemistry's vital contribution to solving water resource problem. Appl. Geochem. 2009, 24, 1058-1073.

4. Bonte, M.; Stuyfzand, P.J.; Hulsmann, A.; Van Beelen, P. Underground thermal energy storage: Environmental risks and policy developments for drinking in the Netherlands and the EU. Ecol. Soc. 2011, 16, Article 22.

5. Haehnlein, S.; Bayer, P.; Blum, P. International legal status of the use of shallow geothermal energy. Renew. Sust. Energ. Rev. 2010, 14, 2611-2625.

6. Park, J.; Sanford, R.A.; Bethke, C.M. Geochemical and microbial zonation of the Middendorf aquifer, South Carolina. Chem. Geol. 2006, 230, 88-104.

7. Jakobsen, R.; Cold, L. Geochemistry at the sulfate reduction-methanogenesis transition zone in an anoxic aquifer-A partial equilibrium interpretation using 2D reactive transport modeling. Geochim. Cosmochim. Acta 2007, 71, 1949-1966.

8. Brons, H.J.; Griffioen, J.; Appelo, C.A.J.; Zehnder, A.J.B. (Bio)geochemical reactions in aquifer material from a thermal energy storage site. Wat. Res. 1991, 25, 729-736.

9. Jesußek, A.; Köber, R.; Grandel, S.; Dahmke, A. Aquifer heat storage: Sulphate reduction with acetate at increased temperatures. Environ. Earth Sci. 2013, 69, 1763-1771.

10. Bonte, M.; Röling, W.F.M.; Zaura, E.; Van der Wielen, P.W.J.J.; Stuyfzand, P.J.; Van Breukelen, B.M. Impacts of shallow geothermal energy production on redox processes and microbial communities. Environ. Sci. Technol. 2013, 47, 14476-14484.

11. Poulton, S.W.; Krom, M.D.; Rijn, J.V.; Raiswell, R. The use of hydrous iron (III) oxides for the removal of hydrogen sulphide in aqueous systems. Wat. Res. 2002, 36, 825-834.

12. Jin, Q.; Bethke, C.M. Cellular energy conservation and the rate of microbial sulfate reduction. Geology 2010, 37, 1027-1030. 
13. Ochifuji, K. Present status and problems of underground thermal energy use and storage. J. Geotherm. Res. Soc. Japan. 2002, 24, 315-327. (in Japanese)

14. Oguchi, T.; Saito, K.; Kadomura, H.; Grossman, M. Fluvial geomorphology and paleohydrology in Japan. Geomorphology 2001, 39, 3-19.

15. Machida, I.; Suzuki, Y.; Takeuchi, M. The ${ }^{14} \mathrm{C}$ age of confined groundwater in a sandy-muddy Pleistocene aquifer. In Groundwater Response to Changing Climate; Taniguchi, M., Holman, I.P., Eds.; CRC Press: Balkema, the Netherlands, 2008.

16. Hama, K.; Kunimaru, T.; Metcalfe, R.; Martin, A.J. The hydrogeochemistry of argillaceous rock formations at the Horonobe URL site, Japan. Phys. Chem. Earth 2007, 32, 170-180.

17. New Energy Vision in Horonobe Area; Horonobe Town: Horonobe Town, Japan, 2002. (in Japanese)

18. Sakoh, S.; Hirota, T.; Sagayama, T.; Yokoyama, E.; Suga, K.; Matsunami, H.; Terashima, K. Hydrogeological Maps of Hokkaido, No. 1, Wakkanai; Geological Survey of Hokkaido: Sapporo, Japan, 1983. (in Japanese)

19. Sakai, T.; Ioka, S.; Igarashi, T. Hydrogeological structure and groundwater flow of alluvium in the south Sarobetsu Moor. J. Jpn. Soc. Eng. Geol. 2012, 53, 172-182. (in Japanese)

20. Sakai, T.; Ioka, S.; Ishijima, Y.; Igarashi, T. Geological analysis of alluvium in the Sarobetsu Moor. J. Jpn. Soc. Eng. Geol. 2011, 52, 2-15. (in Japanese)

21. Parkhurst, J.; Appelo, C.A.J. Description of input and examples for PHREEQC version 3-A computer program for speciation, batch-reaction, one-dimensional transport, and inverse geochemical calculations. In U.S. Geological Survey Techniques and Methods, Book 6; U.S. Department of the Interior: Washington, DC, USA; U.S. Geological Survey: Denver, CO, USA, 2013.

22. Chen, W.-F.; Liu, T.-K. Ion activity products of iron sulfides in groundwaters: Implication from the Choshui fan-delta, Western Taiwan. Geochim. Cosmochim. Acta 2005, 69, 3535-3544.

23. Bethke, C.M. Geochemical and Biogeochemical Reaction Modeling, 2nd ed.; Cambridge University Press: Cambridge, UK, 2008.

24. McMahon, P.B.; Chapelle, F.H. Redox processes and water quality of selected principal aquifer systems. Ground Water 2008, 46, 259-271.

25. Ioka, S.; Sakai, T.; Igarashi, T.; Ishijima, Y. Long-term continuous in-situ potentiometrically measured redox potential in anoxic groundwater with high methane and iron contents. Environ. Earth Sci. 2011, 64, 143-149.

26. Jakobsen, R.; Postma, D. In situ rate of sulfate reduction in an aquifer (Rømø, Denmark) and implications for the reactivity of organic matter. Geology 1994, 22, 1103-1106.

(C) 2014 by the authors; licensee MDPI, Basel, Switzerland. This article is an open access article distributed under the terms and conditions of the Creative Commons Attribution license (http://creativecommons.org/licenses/by/3.0/). 